\title{
NATURE
}

\section{The Deadly Irony of Terrorism}

THE death of Dr Aharon Katchalsky in the wild shooting at Tel Aviv airport last week is not merely an irreparable loss to the scientific community but yet another demonstration that blind terrorism does more to harm than help the causes for which it is supposedly and misguidedly intended. Katchalsky was a versatile and imaginative scientist, as a glance at his most recent work in Nature (234, 393; 1971 and page 332 of this issue) shows: with Drs George Oster and Alan Perelson, his interest then was to apply the mathematical techniques of network theory to the description of irreversible thermodynamic systems. It is not often that a man of 58, buoyed up as Katchalsky was not merely by a passion for science but by a deep interest in the organization of science, the relationship between science and the wider world and a deep concern for the political problems of the world as a whole and of his own country in particular, can turn his mind to the radical revision of the branch of science in which he has worked for most of his life. But the particular irony of Katchalsky's death is that he was conspicuous among Israelis for his concern that something should be done to bring about a rapprochement between Israel and its Arab neighbours. If there can have been, at some remote stage in the planning of this bizarre massacre, a calculation that the act would somehow help the Arab cause, Katchalsky's death is by itself a sufficient proof-if one were needed-that the calculation was absurd.

Terrorism is like this. Over the past few years, the bombings in Northern Ireland, mostly by the two wings of the Irish Republican Army, have done more to prevent a settlement of the longstanding dispute between the Catholic and Protestant communities than to demonstrate that the Catholics have a case. Indeed, the point now seems to have been reached when terrorism is an end in itself. If there were at some distant stage lines of argument that may have persuaded its perpetrators that terrorism might serve some purpose-which is not to suggest that these arguments would have been acceptable to rational people-they have long since been forgotten. What can be done to moderate the pandemic of acts of terrorism as varied as the killings recently reported in central Africa, the perennial threat of indiscriminate slaughter in the Middle East, the trouble in Northern Ireland, incidents such as the bombing of the mathematics building at the University of Wisconsin two years ago and, last week, the hijacking of an aircraft in California in an attempt to secure the release from prison of Miss Angela Davis? The short answer is nothing, for there are no reasons to support the notion that all these assaults on the conventions of civilized society are somehow the products of an efficient subversive international organization. Counter-terrorism has no positive and immediate courses of action open to it. The airlines, for example, must search passengers' baggage and then merely hope for the best. Only by a more widespread acceptance of the belief that civilized institutions are civilizing will terrorism, in the long run, be contained.
The letter on page 357 from an international group of biologists quite properly recognizes that there is very little the scientific community can contribute to relief from terrorism, but the signatories are also right in urging that the events last week at Tel Aviv will not be followed by retaliation and counter-retaliation. That would be pointless and in the end would create still further obstacles to a political settlement in the Middle East. So how best to contain the frustration which comes from the feeling that "something should be done"? This is where the proposal that there should be a Katchaisky Memorial Fellowship at the Weizmann Institute has sprung from. For one thing, fellowships are good things anyway. For another, the breadth of Katchalsky's interest would provide a splendid opportunity for recruiting scientists and others of various disciplines to the place to which he was most attached. And there is always the hope that a permanent memorial to Katchalsky in this form would serve as a perpetual reminder of the futility of terrorism. At this stage, the first need is to know what the scientific community thinks of the proposal. Further details of the practical arrangements will be available a week from now.

\section{Siandard Liferature}

THOSE who would standardize the scientific literature will unhappily be buoyed up by the publication, in the past few weeks, of British Standard 4811: 1972, Specification for the presentation of research and development reports. The objective is plausible enough. The preamble to the new standard says that since the Second World War, research and development reports have become a distinctive part of the literature of rapid communication in science and technology and goes on to say that steps must be taken to ensure that readers of these reports should be given as much help as possible in understanding them. So far, so good, but whether this need is met by a standardization of the format of research and development reports is another matter. The new standard suggests that authors should first define their objectives in writing a report, gather the information it will contain and then analyse that information. There should follow, the standard says, a section concerned with the conclusions and then a summary. There is a list of detailed headings under which these various components of a research and development report might be included. Nobody will quarrel with the general idea that authors should know what they intend to write before they put pen to paper nor even the suggestion that pages should be numbered (though why the title page of a report should necessarily be called page 1 is entirely another matter). But is it really sensible to claim that the great variety of $R$ and $D$ reports can all fit into the same framework?

Sometimes, for example, research and development reports produced by research institutes and 